\title{
The epidemiology of age-related hearing loss, social aspects and interaction with chronic disease of older adults
}

\author{
U Barillari \\ From de Senectute: Age and Health Forum \\ Catanzaro, Italy. 5-7 December 2009
}

Hearing loss is one of the most prevalent chronic conditions affecting older adults. In U.S. studies, prevalent estimates of hearing loss in adults aged 65 and older range from $30 \%$ to $83 \%$ depending upon the definition used. European studies suggest a steady decline in hearing from the sixth to ninth decades.

Although age-related hearing loss is not life-threatening, it affects quality of life and can have a negative effect on a person's health. It diminishes an individual's ability to communicate effectively, jeopardizes one's autonomy, and has been correlated with an increased incidence of clinical depression and social isolation.

These findings highlight the need for improved methods of identifying individuals with age-related hearing loss and improving services for providing hearing aids, and auditory rehabilitation. Identifying individuals with hearing loss and supplying appropriate hearing aids and teaching coping strategies may have a positive impact on quality of life for older people.

Published: 19 May 2010

\section{Reference}

1. Barillari U, Angelillo N, d'Anna G: Aspetti foniatrici della comunicazione del paziente anziano affetto da ipoacusia. Ant Med It 2001, 21:504-509.

doi:10.1186/1471-2318-10-S1-L49

Cite this article as: Barillari: The epidemiology of age-related hearing loss, social aspects and interaction with chronic disease of older adults. BMC Geriatrics 2010 10(Suppl 1):L49.

Service of Phoniatry and Audiology, Second University of Naples, Naples, Italy

BioMed Central @ 2010 Barillari; licensee BioMed Central Ltd.
Submit your next manuscript to BioMed Central and take full advantage of:

- Convenient online submission

- Thorough peer review

- No space constraints or color figure charges

- Immediate publication on acceptance

- Inclusion in PubMed, CAS, Scopus and Google Scholar

- Research which is freely available for redistribution

Submit your manuscript at www.biomedcentral.com/submit
( Biomed Central 